\title{
ANALISIS KOMPARATIF BANK SYARIAH DAN BANK KONVENSIONAL DI INDONESIA
}

\author{
Rudi Purnomo \\ Jl. Gundih 3/44A Surabaya \\ rudip@gmail.com
}

Masning Syarifah

Jl. Sunan Giri 4 No. 28 Kebomas Gresik

syarifation@gmail.com

\author{
Ali Makki Hodri \\ Bank DKI Kramat Jati, Jakarta Timur \\ mackyilwa@gmail.com
}

\begin{abstract}
This article discusses a comparative analysis of Islamic banks and conventional banks. This article is the result of a literature review and is qualitative. The collected data is analyzed in a comparative manner between Islamic banks and conventional banks which include: sources of funds, Distribution and Use of Bank Funds, Bank Services, advantages and disadvantages of Islamic banks and conventional banks. About sources of funds, conventional banking sources of funds are: Funds originating from within the bank (internal) and funds originating from outside the bank (external). The source of funds for a Sharia Bank is in its capacity as a mudharib by using funds obtained from customers as Shahib al-Mal, who deposit and invest their funds in the bank through the following accounts: Current Account (pure al-Wadiah savings principle), Savings Account, Account general investment, special investment account. About the Distribution and Use of Funds, in conventional banks the funds that have been collected by banks must then be allocated through the Use of Funds for Assets, Use of Funds for Reserves, Use of Funds for Credit, Use of Funds for Securities, Use of Funds for Participation. Distribution and Use of Funds in Sharia Banks are through financing products with profit sharing principles, sale and purchase principles and leasing and qard hasan. Conventional bank services are Letter of Credit (L / C), Clearing, Bank Guarantee, Collection, Travel Check (travelers check), Remittance, Credit Card (credit card), Safe Deposit Box, Phone Banking, Cash Management , and Money Transfer (Transfer). The services offered at Islamic banks are Rahn, Wakalah, Kafalah Hawalah, Ji'alah, Sharf. Regarding the advantages and disadvantages of conventional banks and Islamic banks, both have their respective advantages and disadvantages.
\end{abstract}

Keywords: Islamic bank, conventional bank, product, comparative.

Abstrak: Artikel ini membahas tentang analisis komparatif tentang bank syariah dan bank konvensional. Artikel ini merupakan hasil dari kajian pustaka dan bersifat kualitatif. Data yang terkumpul dianalisis secara komparatif antara bank syariah dan bank konvensional yang meliputi: sumber dana, Penyaluran dan Penggunaan Dana

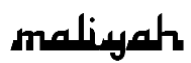

Jurnal Hukum Bisnis Islam

Volume 8, Nomor 1, Juni 2018

p-ISSN: 2088-4869/ e-ISSN: 2597-4351 
Bank, Jasa-Jasa Bank, keunggulan dan kelemahan bank syariah dan bank konvensional. Berkaitan dengan sumber dana, sumber dana perbankan konvensional adalah: Dana yang bersumber dari dalam bank (internal) dan dana yang bersumber dari luar bank (eksternal). Sumber dana Bank Syariah adalah dalam kapasitasnya sebagai mudharib dengan menggunakan dana yang diperoleh dari para nasabah sebagai Shahib al-Mal, yang menyimpan dan menanamkan dananya pada bank melalui rekening-rekening: Rekening Koran (prinsip simpanan murni alWadiah), Rekening Tabungan, Rekening investasi umum, Rekening investasi khusus. Berkaitan dengan Penyaluran dan Penggunaan Dana, pada Bank Konvensional dana yang telah dihimpun oleh perbankan kemudian harus dialokasikan melalui Penggunaan Dana untuk Aktiva, Penggunaan Dana untuk Cadangan, Penggunaan Dana untuk Kredit, Penggunaan Dana untuk Surat-surat Berharga, Penggunaan Dana untuk Penyertaan. Penyaluran dan Penggunaan Dana di Bank Syariah adalah melalui Produk pembiayaan dengan Prinsip Bagi hasil, prinsip jual beli dan sewa menyewa dan qard hasan. Jasa-jasa bank konvensional adalah Letter of Credit (L/C), Kliring, Bank Garansi, Inkaso (collection), Cek Perjalanan (travelers cheque), Remittance, Kartu Kredit (credit card), Safe Deposit Box, Phone Banking, Cash Management, dan Pengiriman Uang (Transfer). Jasa-jasa yang ditawarkan di bank syariah adalah Rahn, Wakalah, Kafalah Hawalah, Ji'alah, Sharf. Berkaitan dengan Keunggulan dan Kelemahan Bank Konvensional dan Bank Syariah, keduanya memiliki keunggulan dan kelemahannya masing-masing.

Kata Kunci: bank syariah, bank konvensional, produk, komparatif.

\section{Pendahuluan}

Bank sebagai lembaga intermediasi dalam pengelolaan dana, mempunyai posisi strategis dalam mendorong pertumbuhan ekonomi. Peran intermediasi bank merupakan amanah yang harus dijalankan dengan tetap mengedepankan prinsip keadilan. Sehingga timbullah dua model bank yakni konvensional dan syariah. Masing-masing menonjolkan keunggulan dan keuntungan menabung di bank miliknya dengan menampilkan bentuk manajemen operasionalnya. Persaingan pun terjadi untuk merebut hati nasabah.

Kata bank berasal dari bahasa Italia banque atau Italia banca yang berarti bangku. Para bankir Florence pada masa Renaissans melakukan transaksi mereka dengan duduk di belakang meja penukaran uang, berbeda dengan pekerjaan 
kebanyakan orang yang tidak memungkinkan mereka untuk duduk sambil bekerja. ${ }^{1}$

Arti dari kata bank sendiri adalah sebuah lembaga intermediasi keuangan umumnya didirikan dengan kewenangan untuk menerima simpanan uang, meminjamkan uang, dan menerbitkan promes atau yang dikenal sebagai banknote. ${ }^{2}$ Arti dari intermediansi atau lembaga penyaluran keuangan untuk sistem transfer antara lembaga keuangan yang lain. Dari tempat menyimpan uang, tempat simpan pinjam itu terdapat semua dari tugas dari bank itu sendiri.

Sedangkan menurut undang-undang perbankan, ${ }^{3}$ Undang-undang Negara Republik Indonesia Nomor 10 Tahun 1998, bank adalah badan usaha yang menghimpun dana dari masyarakat dalam bentuk simpanan dan menyalurkannya kepada masyarakat dalam bentuk kredit dan atau bentukbentuk lainnya dalam rangka meningkatkan taraf hidup rakyat banyak. $^{4}$

Pada dasarnya peranan perbankan konvensional dalam lembaga kegiatan ekonomi sama dengan perbankan Islam, sebagai lembaga dan penyaluran. Adapun perbedaan yang paling menyolok adalah bahwa bank konvensional mempunyai pranata bunga, sedangkan bank Islam menggunakan sistem bagi hasil.

Berdasarkan hal tersebut, artikel ini membahas perbandingan bank syariah dan bank konvensional.

\section{Sejarah Perbankan di Indonesia}

Kegiatan perbankan sebenarnya telah dipakai oleh manusia sejak dulu, hanya saja apakah kegiatan mereka

\footnotetext{
1 Martim de Albuquerque, Notes and Queries (London: George Bell, 1855), http://books.google.com/?id=uIrWLegNZxUC\&pg=PA431\&lpg=PA431\&dq=b ank+italian+bench, 431.

2 N. F. Hoggson, Banking Through the Ages (New York: Dodd, Mead \& Company, 1926).

3 Undang-Undang Negara Republik Indonesia Nomor 10 Tahun 1998 Tentang Perbankan, n.d.

${ }^{4}$ Kasmir, Manajemen Perbankan (Jakarta: Rajawali Press, 2000).
} 
tersebut masuk dalam kriteria perbankan modern? Hal ini belum dapat dilacak dengan pasti, hanya catatan sejarah yang mencoba mengungkapkan kebenarannya walau dalam taraf sejauh sejarah dapat menjamah dengan yang valid.

Di belahan Negara Timur jauh sampai ke Asia kecil (Turki) pada kurun waktu 5000 tahun, Bangsa Sumeria sudah mulai dilakukan kegiatan perbankan. Di samping itu, bangsa Babylonia telah melakukan aktifitas perbankan seperti simpan pinjam, pengadaan perjanjian kredit dan sebagainya. ${ }^{5}$ Adapun di belahan benua Eropa dan Afrika, kegiatan perbankan juga berlangsung sejak kurang lebih 2500 tahun, seperti di Mesir Purba, Yunani Purba, Yunani Kuno dan Romawi. ${ }^{6}$

Perkembangan Perbankan konvensional di Amerika belum seramai sebagaimana kegiatan perbankan di daratan Eropa. Selama bertahun-tahun aktifitas perbankan banyak didominasi oleh perbankan Eropa. Mulai dari abad ke XII sampai pada abad XIX, bank di Italia sangat menonjol dalam hal keuangannya, seperti bank-bank di Genoa (1404), Venesia (1587) dan Milan (1593). Bank di Belgia dan Belanda cukup berperan dalam dunia perbankan, apalagi setelah dibentuknya Bank of England, sehingga Inggris menjadi pusat sirkulasi bank dunia. Prestasi ini dipegang sampai Perang Dunia II. Namun seiring dengan itu perbankan di Amerika, lambat laun mulai memasuki pergulatan perbankan di dunia, setelah disahkannya Federal Reservec Act tahun 1913, pintu telah terbuka bagi perbankan Amerika untuk berkiprah dan bersaing (survive). Disusul pada tahun1916 Federal Reserve Act mengizinkan perbankan nasional untuk melakukan investasi yang bergerak dalam bidang perbankan dunia (internasional). ${ }^{7}$

Peran perbankan Amerika tidak dapat diabaikan karena Amerika salah satu negara yang menang perang dalam perseteruan perang dunia II. Sehingga pasca perang dunia II,

\footnotetext{
${ }^{5}$ Thomas Suyatno, Kelembagaan Perbankan (Jakarta: Gramedia, 1987), 12.

6 Hasan Shadily, Ensiklopedia Indonesia (Jakarta: Ikhtiar Baru van Hoeve, 1966), 394.

${ }^{7}$ Edward W Reed and Edward K Gill, Bank Umum, Penerjemah St. Dianjung (Jakarta: Bina Aksara, 1995), 368.
}

\section{malinath}


Amerika tidak memiliki kendala yang berarti dalam kegiatan perbankannya. Pada akhir tahun 1982 terhadap 14.963 bank di Amerika, walaupun kwantitas itu sangat berfluktuasi dengan berjalannya waktu. Jika menengok sejarah yaitu pada tahun 1940 Amerika mempunyai kurang lebih 800 buah bank, tahun 1900 menjadi 9000 buah bank, tahun 1920 hampir mencapai 30.000 buah bank. Tetapi antara 1920-1940 bank-bank di Amerika jumlahnya menurun lebih dari 50\%, karena berbagai bank melakukan merger untuk menghindari kebangkrutan akibat isu perang dunia II. ${ }^{8}$

Sebelum perang dunia II pada tahun 1920 konferensi keuangan internasional yang diadakan di Brussel Belgia, mengeluarkan resolusi agar setiap negara memiliki bank. Hal tersebut ditindaklanjuti di Afrika Selatan dengan berdirinya South Africa Reserve, Bank China dan National Bank of Iran pada tahun 1928. Pada tahun 1935 di India berdiri Reserve Bank of India, sedangkan pada tahun 1942 berdiri pula Bank of Thailand. Adapun pasca perang dunia II, berbagai bank tumbuh di beberapa negara Asia lainnya, seperti: State Bank of Pakistan (1948), National Bank of Iraq (1949) dan Bank of Korea (1950). ${ }^{9}$ Adapun di Amerika, berbagai bank Amerika mulai merambah ke mancanegara seperti kapulauan Bahama dan Cayman. Sedangkan di Eropa Bank of America bergabung dengan Banque Nationale de Paris (Perancis), Banca Nazionale del Lavoro (italia), Barelays Bank (Inggris), the Dredsner Bank (Jerman), Banqu de Bruxelles (Belgia) dan Algemene Bank Nederland (Belanda), untuk membentuk organisasi perbankan baru yang dinamanakan Societe Financeiere Europeene. ${ }^{10}$

Sejarah perbankan ini dapat diklasifikasikan dalam beberapa periode yang terurai dalam keterangan dibawah ini:

\footnotetext{
${ }^{8}$ Stephen M. Goldfeld and Lester V. Chanler, Ekonomi, Uang Dan Bank, Terj. A. Hasjmi Ali (Jakarta: Bina Aksara, 1988), 105-106.

9 Dawam Raharjo, Bank Indonesia Dalam Kilasan Sejarah Bangsa (Jakarta: LP3ES, 1995), 24.

10 Edward B. Reed and Edward K. Gill, Bank Umum Terj. St. Dianjung (Jakarta: Binai Aksara, 1995), 371.
} 
1. Periode penjajahan Belanda sampai kependudukan Jepang (1827-1942)

Pada periode ini bank-bank di Indonesia dapat digolongkan sebagai berikut:

a. Bank milik Belanda, seperti: De Javasche Bank berdiri pada tanggal 11 Oktober 1827, Esconto Bank (1857), De Nederlandsch Indische Bank (1863), Roterdamsche Bank (1864) pada akhirnya De Javasche bank diganti dengan nama Bank Indonesia pada tahun1953.

b. Bank milik Tionghoa; The Overseas Chineses banking Coorperation, The Banking of China, Batavia Bank, Changhua Sangieh Maatscapirjj, Bank Vereneeging Oei Tionghan.

c. Bank milik Inggris; The Caracter Bank of India, Australia and China dan The Hongkong and Shanghai Banking Coorperation.

d. Bank milik Jepang; The Bank of Taiwan, The Yokohama Species Bank dan Mitsui Bank.

e. Bank milik pribumi; Batakche bank didirikan di Pematang Siantar dan Algiomene Volkerediet Bank (AVB). ${ }^{11}$

2. Periode pendudukan Jepang sampai proklamasi kemerdekaan (1942-1945)

Pada tanggal 20 Oktober 1942 semua bank Belanda, Inggris dan Tionghoa dinyatakan dilikuidsi. Namun AVB tidak dilikuidasi, sedang kegiatan-kegiatan bank-bank yang lain dilanjutkan oleh lembaga kredit Jepang yang bernama Syamin Ginko. Kemudian pemerintah Jepang mendirikan Nanpo Kaihatsu Ginko sebagai bank sirkulasi.

3. Periode kemerdekaan sampai orde baru (1945-1967)

Pada periode ini, berdiri bank pemerintah yaitu BNI pada tanggal 4 Juli 1946, BRI tanggal 22 Februari 1946 dan bankbank lain diberbagai daerah Indonesia. Adapun bank swasta berdiri pada tahun 1951 seperti Bank Industri Negara (BIN), Bank Pembangunan Indonesia (BPI). Pada tahun1958, pemerintah menasioalisasikan berbagai bank yang berbau

\footnotetext{
${ }^{11}$ Muchdarsyah Sinungan, Uang Dan Bank (Jakarta: Rineka Cipta, 1991), 136.
} 
Belanda, sehingga muncul nama-nama baru, seperti Bank Dagang Negara (BDN), Bank Umum Negara (BUN) dan Bank Koperasi Tani dan Nelayan (BKTN). Di sisi lain pemerintah mengadakan pengintegrasian berbagai bank, seperti BI menjadi BNI unit 1, BKTN menjadi BNI unit 2, BNI sendiri menjadi unit 3, BUN menjadi BNI unit 4, dan BTN menjadi BNI unit $5 .{ }^{12}$

4. Periode perbankan setelah 1967 sampai sekarang ${ }^{13}$

Pada periode ini muncul UU No. 14 tahun 1967. Dimana pemerintah mengajukan UU tersebut kepada DPRGR yang selanjutnya disetujui oleh presiden, sehingga mulai Januari 1968 undang-undang tersebut dapat dilaksanakan dengan mengoperasikan BNI unit 1 sebagai bank sentral. UU No. 17 tahun 1968 tentang BNI 1946 menggantikan BNI unit 3 yang beroperasi di sektor industri. UU No. 181968 tentang BDN menggantikan BNI unit 2 yang beropersi di sektor pertambangan, UU No. 19 tahun 1968 tentang BBD yang menggantikan BNI unit 4 yang bergerak di sector simpan pinjam. UU No. 21 tentang BRI yang menampung BNI unit 2 yang beroperasi di sektor operasi, tani dan nelayan. UU No. 22 tahun 1968 tentang Bank Exim yang menampung BNI unit 2 yang beroperasi di sektor produksi pengolahan dan pemasaran bahan-bahan ekspor. ${ }^{14}$

\section{Sejarah Perbankan Islam di Dunia}

Pada dasarnya, gagasan konsep teoritis tentang bank Islam telah muncul pada tahun awal 1940-an. Namun untuk mendirikan bank Islam belum bisa terealisir, karena kondisi pada saat itu yang tidak memungkinkan. Selain itu, belum adanya pemikiran tentang bank Islam yang meyakinkan. ${ }^{15}$

Bank Islam telah dikenal secara luar di dunia Islam maupun barat sebagaimana dikemukakan oleh Abdullah Saeed

\footnotetext{
12 Ibid., 146-147.

${ }^{13}$ Ibid., 121.

14 Raharjo, Bank Indonesia Dalam Kilasan Sejarah Bangsa, 176.

15 W Sumitro, Asas-Asas Perbankan Islam Dan Lembaga-Lembaga Terkait (BMUI \& Takaful) Di Indonesia (Jakarta: Raja Grafindo Persada, 1996), 8.
} 
bahwa pada pertengahan 1970-an, bank-bank Islam telah tumbuh dan berkembang pesat. bank-bank tersebut telah dibangun tidak hanya di negara-negara yang mayoritas pemeluknya Islam, seperti Mesir, Yordania, Sudan, Bahrain, Kuwait, UEA, Tunisia, Mauritania, dan Malaysia tetapi juga di Inggris Raya, Denmark dan Filipina yang pemeluk Islamnya minoritas. ${ }^{16}$

Sejauh perkembangan bank Islam modern diawali dengan berdirinya Mit Ghamr Local Saving Bank of Egypt di Mesir. Akibat situasi politik saat itu, bank ini diambil oleh National Bank of Egypt dan Central Bank of Egypt pada pertengahan tahun 1967. Selain itu pada tahun 1972, sistem bank tanpa riba diperkenalkan lagi di Mesir dengan berdirinya Naseer Social Bank. ${ }^{17}$

Perlu dicermati bahwa lahirnya gagasan tentang perlunya suatu lembaga keuangan alternatif yang beroperasi sesuai dengan prinsip syariat Islam berawal dari pemikiran para ulama dan pakar ekonomi Organisasi Konferensi Islam (OKI). OKI sendiri dibentuk awal tahun 1970-an yang diprakarsai oleh Raja Faisal dari Arab Saudi, yang menyarankan bahwa tiap negara Islam agar mendirikan bank Islam. Berdirinya OKI mendorong terbentuknya Islamic Development Bank (IDB), yang pada konferensi ke 2, menteri luar negeri negara-negara Islam pada bulan Desember 1970 di Karachi-Pakistan, telah diagendakan tentang gagasan berdirinya IDB yang penugasannya diserahkan Sekretaris Jenderal OKI untuk menjajaki kemungkinan didirikannya IDB. ${ }^{18}$

Pada konferensi Islam pertama menteri-menteri keuangan OKI di Jeddah-Arab Saudi, pada tanggal 16 desember 1973 membahas tentang drag agreement berdirinya IDB, yang kemudian berhasil di tandatanganinya Declaration of Intent for the Establishment of an Islamic Development Bank, pada tanggal

\footnotetext{
${ }^{16}$ Abdullah Saeed, Islamic Banking and Interest (Leiden: EJ. Brill, 1996), 1.

${ }_{17}$ Zainul Arifin, Memahami Bank Syariah: Lingkup, Peluang, Tantangan, Dan Prospek (Jakarta: Alfabet, 1999), 11.

${ }^{18}$ Sumitro, Asas-Asas Perbankan Islam Dan Lembaga-Lembaga Terkait (BMUI \& Takaful) Di Indonesia, 52.
}

\section{maliyath}


16 Desember 1973 yang ditandatangani oleh 23 negara peserta, termasuk Indonesia. Sehingga pada tanggal 10-12 Agustus 1974 di Jeddah disetujui secara resmi pembentukan IDB pada siding ke-2 menteri-menteri keuangan OKI. ${ }^{19}$

Pada tanggal 23 April 1975, IDB dinyatakan berdiri secara efektif setelah dipenuhinya semua ketentuan dalam anggaran dasarnya. Adapun sidang pembukaannya diselenggarakan di Riyadh pada tanggal 26-28 Juli $1975 .^{20}$

Dalam perkembangannya, IDB membantu berdirinya berbagai bank Islam di mancanegara OKI di seluruh dunia. Hal ini dilakukan IDB untuk menggerakkan pertumbuhan ekonomi serta meningkatkan kesejahteraan bagi negara-negara anggota dan masyarakat Islam secara umum.

Ide pendirian bank Islam (bank Syari'ah) bermula dari lokakarya mengenai "bunga bank dan perbankan" yang diselenggarakan oleh MUI di Cisarua tanggal 18-20 Agustus 1990. Gagasan itu kemudian dipertegas lagi dalam musyawarah nasional IV MUI di hotel Sahid Jaya, Jakarta pada tanggal 22-25 Agustus 1990. Atas dasar amanat munas IV MUI inilah langkah pertama untuk mendirikan bank syariah Indonesia dimulai. ${ }^{21}$

Setelah munas IV, MUI membentuk tim kerja yang diketuai oleh DR. Ir. Amin Aziz. Tim ini bertugas untuk mempersiapkan segala sesuatu yang berkaitan dengan berdirinya bank Islam di Indonesia. Untuk membantu kelancaran tugas-tugas tim MUI, dibentuk tim hukum Ikatan Cendekiawan Muslim Indonesia (ICMI) yang diketuai oleh Drs. Karnaen Parwaatmadja, MPA. Tim ini bertugas untuk mempersiapkan berbagai aspek yang berkaitan dengan aspek hukum dari bank Islam. ${ }^{22}$

\footnotetext{
19 Ibid., 53.

${ }^{20}$ Karnaen A. Perwataatmadja and Syafi'i Antonio, Apa Dan Bagaimana Bank Syariah (Yogyakarta: Dana Bhakti Wakaf, 1992), 58.

${ }^{21}$ Sofyan Syafii Harahap, Akuntansi Islam (Jakarta: Bumi Aksara, 1997), 108.

22 Sumitro, Asas-Asas Perbankan Islam Dan Lembaga-Lembaga Terkait (BMUI \& Takaful) Di Indonesia, 73.
} 
Tim MUI, selain mempersiapkan proses berdirinya bank Islam, baik dari segi administrasi maupun pendekatanpendekatan konsolidasi dengan berbagai pihak terkait, juga menyiapkan aspek SDM dengan menyelenggarakan training calon staf bank Islam melalui "Management Development Program" di lembaga pengembangan perbankan Indonesia, sekarang menjadi institute banking Indonesia, yang dibuka oleh menteri muda keuangan Nasruddin Sumentapura pada tanggal 29 Maret 1991.23

Bank muamalat Indonesia (BMI) sebagai lembaga keuangan Islam pada awal berdirinya membutuhkan dana yang tidak sedikit, maka tim MUI mengadakan berbagai lobi kepada para pengusaha muslim nasional untuk menjadi pemegang saham. Disamping adanya inisiatif lain, ketika menteri Ginanjar Kartasasmita dari beberapa menteri lain mengumpulkan para konglomerat di hotel Sahid Jakarta sehingga terkumpul modal yang besar dari para konglomerat itu. ${ }^{24}$

Dukungan umat Islam terhadap berdirinya BMI sangat antusias, hal itu dibuktikan dengan kerja keras tim MUI selama satu tahun sejak gagasan berdirinya, BMI dapat dilaksanakan sehingga buah dari kerja keras tersebut terealisir dengan ditandatanganinya akta pendirian BMI di Sahid Jaya hotel berdasarkan akta notaris no. 1 tanggal 1 November 1991 dengan izin menteri kehakiman no. C2.2413.HT01 tanggal 21 Maret 1992/Berita Negara RI tanggal 28 April 1992 no. 34 surat menteri keuangan RI no.1223/MK.013/1991 tanggal 5 November 1991 dan izin usaha berdasarkan keputusan menteri keuangan RI No. 430/KMK.013/1992 tanggal 24 April 1992, kemudian pada tanggal 15 Mei 1992 dalam grand opening yang dilakukan dengan penandatanganan prasasti oleh wakil presiden RI waktu itu Soedharmono, $\mathrm{SH}_{\text {., }}{ }^{25}$ sehingga diharapkan BMI mampu melayani harapan masyarakat melalui jasa-jasanya.

\footnotetext{
${ }^{23}$ Ibid, 74.

${ }^{24}$ Harahap, Akuntansi Islam, 108.

25 Ibid., 109,
} 
Sejak tahun 1992 Indonesia telah memiliki BMI sebagai bank syariah pertama yang terus berkembang menjadi beberapa cabang di berbagai daerah di Indonesia, yang kemudian disusul dengan berdirinya Bank Syariah Mandiri sebagai bank syariah kedua. ${ }^{26}$ Selain yang disebut di atas di Indonesia berkembang pula bank perkreditan rakyat syariah. ${ }^{27}$ Seperti BPRS Amal Sejahtera, Dana Mardlatillah dan Amanah Rabbaniyyah yang semua beroperasi di wilayah Bandung. ${ }^{28}$

Tujuan didirikannya BMI didasarkan pada strategi usaha dengan pembinaan dan pengembangan. Sasaran pembinaan BMI yaitu membina dan mempercepat berkembangnya masyarakat ekonomi menengah ke bawah dan untuk menjembatani kesenjangan sosial ekonomi yang terjadi, adapun strategi BMI adalah: ${ }^{29}$

1. Bekerja sama dengan bank perkreditan rakyat syariah yang telah ada.

2. Mendukung perkembangan bank perkreditan rakyat syariah di berbagai daerah yang potensial.

3. Bekerjasama dengan badan amil zakat infaq dan sodaqoh dalam pengelolaan dana agar lebih intensif bagi pengembangan usaha kecil dan menengah.

4. Mendorong kepada lembaga penyedia dana untuk penanganan yang baik dan teratur.

5. Merangsang para penyedia peralatan teknologi untuk meningkatkan produktifitas.

6. Merangsang lembaga-lembaga penyedia bantuan pembinaan keterampilan akuntansi.

7. Mengembangkan peran kelembagaan dan melancarkan jaringan penyedia bahan baku.

\footnotetext{
26 Ahmad Tohirin, "Sewindu Bank Syariah Indonesia," Harian Kedaulatan Rakyat (Yogyakarta, April 2000).

${ }^{27}$ Arifin, Memahami Bank Syariah: Lingkup, Peluang, Tantangan, Dan Prospek, 133.

28 A. Perwataatmadja and Antonio, Apa Dan Bagaimana Bank Syariah, 107108.

${ }^{29}$ Ibid, 86.
} 
8. Mengembangkan peran kelembagaan pemasaran hasil produksi.

\section{Urgensi Bank Syariah}

Bisnis secara syariah adalah aktivitas bisnis yang syarat dan berorientasi pada nilai. Dengan demikian pelaporan atas aktivitas dan hasilnya harus dilaporkan/dilakukan berdasarkan prinsip-prinsip syariah. Untuk mencapai tegaknya sasaran pokok tersebut maka perlu adanya penyiapan sistem akutansi untuk praktek bisnis berdasarkan syariah. Ini dilakukan dengan tujuan untuk menyiapkan para pelaku akutansi di lembaga bisnis berdasarkan Syar'i, khususnya berkaitan dengan bagaimana menghitung keuntungan dan kerugian dari transaksi yang dilakukan. ${ }^{30}$

Adapun prinsip-prinsip yang dirujuk adalah:

1. Dilarang menerapkan bunga pada semua bentuk dan jenis transaksi.

2. Pembagian yang seimbang. Islam mendorong orang muslim untuk menanam uang mereka dan menjadi partner dengan tujuan berbagi keuntungan dan resiko.

3. Melarang gharar, dibawah larangan ini, transaksi ekonomi yang dimasuki harus bebas dari ketidakpastian, resiko dan spekulasi.

4. Kontrak yang suci, bank Islam memegang tanggung jawab kontrak dan berkewajiban untuk memberikan informasi secara utuh

5. Bekerjasama dalam membangun masyarakat melalui aktivitas bisnis dan perdagangan yang tidak dilarang oleh Islam.31

Fungsi-fungsi bank yang diuraikan di bawah ini menujukkan betapa pentingnya keberadaan bank saat ini, yaitu:

1. Mendukung kelancaran mekanisme pembayaran

\footnotetext{
${ }^{30}$ Muhammad, Audit \& Pengawasan Syariah Pada Bank Syariah, n.d.

${ }^{31}$ Veithzal Rivai and Arviyan Arifin, Islamic Banking: Sebuah Teori, Konsep, Dan Aplikasi (Jakarta: Bumi Aksara, n.d.).
} 
Fungsi lain dari bank umum yang juga sangat penting adalah mendukung kelancaran mekanisme pembayaran. Hal ini dimungkinkan karena salah satu jasa yang ditawarkan bank umum adalah jasa-jasa yang berkaitan dengan mekanisme pembayaran.

Beberapa jasa yang amat dikenal adalah kliring, transfer uang, penerimaan setoran-setoran, pemberian fasilitas pembayaran dengan tunai, kredit, fasilitas-fasilitas pembayaran yang mudah dan nyaman, seperti kartu plastik dan sistem pembayaran elektronik.

2. Penghimpunan dana simpanan masyarakat

Dana yang paling banyak dihimpun oleh bank umum adalah dana simpanan. Di Indonesia dana simpanan terdiri atas giro, deposito berjangka, sertifikat deposito, tabungan dan atau bentuk lainnya yang dapat dipersamakan dengan itu. Kemampuan bank umum menghimpun dana jauh lebih besar dibandingkan dengan lembaga-lembaga keuangan lainnya. Dana-dana simpanan yang berhasil dihimpun akan disalurkan kepada pihak-pihak yang membutuhkan, utamanya melalui penyaluran kredit.

3. Mendukung kelancaran transaksi internasional

Bank umum juga sangat dibutuhkan untuk memudahkan dan atau memperlancar transaksi internasional, baik transaksi barang/jasa maupun transaksi modal. Kesulitankesulitan transaksi antara dua pihak yang berbeda negara selalu muncul karena perbedaan geografis, jarak, budaya dan sistem moneter masing-masing negara. Kehadiran bank umum yang beroperasi dalam skala internasional akan memudahkan penyelesaian transaksi-transaksi tersebut. Dengan adanya bank umum, kepentingan pihak-pihak yang melakukan transaksi internasional dapat ditangani dengan lebih mudah, cepat, dan murah.

4. Penyimpanan barang-barang berharga

Penyimpanan barang-barang berharga adalah satu satu jasa yang paling awal yang ditawarkan oleh bank umum. Masyarakat dapat menyimpan barang-barang berharga yang dimilikinya seperti perhiasan, uang, dan ijazah dalam kotak- 
kotak yang sengaja disediakan oleh bank untuk disewa (safety box atau safe deposit box). Perkembangan ekonomi yang semakin pesat menyebabkan bank memperluas jasa pelayanan dengan menyimpan sekuritas atau surat-surat berharga.

5. Pemberian Jasa-Jasa Lainnya

Di Indonesia pemberian jasa-jasa lainnya oleh bank umum juga semakin banyak dan luas. Saat ini kita sudah dapat membayar listrik, telepon membeli pulsa telepon seluler, mengirim uang melalui ATM, membayar gaji pegawai dengan menggunakan jasa-jasa bank.

\section{Operasional Bank Konvensional dan Bank Syariah}

Berikut dibahas tentang operasional bank konvensional dan bank syariah yang meliputi: sumber dana, penyaluran dan penggunaan dana bank, jasa-jasa bank, keunggulan dan kelemahan bank syariah dan bank konvensional:

1. Sumber dana

a. Sumber Dana Bank Konvensional

Terdapat dua sumber bagi kelangsungan usaha perbankan konvensional di Indonesia yaitu:

1) Dana yang bersumber dari dalam bank (internal)

2) Dana yang bersumber dari luar bank (eksternal)

Untuk lebih jelasnya, sumber dana bank dapat kita lihat pada tabel berikut:

\begin{tabular}{|c|c|c|}
\hline Sumber Dana & Asal & Contoh \\
\hline $\begin{array}{l}\text { 1. Internal } \\
\text { (dari dalam } \\
\text { bank) }\end{array}$ & $\begin{array}{l}\text { Bank } \\
\text { bersangkutan }\end{array}$ & $\begin{array}{ll}\text { - } & \text { Modal } \\
\text { - } & \text { Cadangan } \\
\text { - } & \text { Keuntungan } \\
& \text { yang belum } \\
& \text { dibagikan } \\
\text { - } & \text { Penjualan } \\
& \text { saham, agio } \\
& \text { saham }\end{array}$ \\
\hline $\begin{array}{ll}\text { 2. } & \text { a. Eksternal } \\
\text { (dari luar }\end{array}$ & Masyarakat & $\begin{array}{ll}\text { - } & \text { tabungan } \\
\text { - } & \text { deposito } \\
\text { - } & \text { giro } \\
\text { - } & \text { setoran jaminan }\end{array}$ \\
\hline
\end{tabular}

\section{maliyath}




\begin{tabular}{|c|c|}
\hline bank) & - transfer \\
\hline $\begin{array}{l}\text { b. Eksternal } \\
\text { (dari luar } \\
\text { bank) }\end{array}$ & $\begin{array}{l}\text { - } \text { call money } \\
\text { - pinjaman antar } \\
\text { bank } \\
\text { - } \text { BLBI } \\
\text { - } \text { SBPU } \\
\text { - Fasilitas } \\
\text { diskonto }\end{array}$ \\
\hline
\end{tabular}

Pada umumnya dana yang bersumber dari bank sendiri mempunyai proporsi yang rendah jika dibandingkan dengan dana yang bersumber dari bank. Namun, dana itu sendiri merupakan hal penting bagi kelangsungan usaha bank bersangkutan, karena bersifat permanen dan terus mengendap selama bank tersebut berdiri. Dana yang bersumber dari bank adalah: 1) Modal yang disetor oleh pemegang saham 2) Cadangan-cadangan 3) Keuntungan yang belum dibagikan ke pemegang saham 4) Dana dari penjualan saham dari bursa 5) Agio saham

Dana yang bersumber dari luar bank terdiri dari dua sumber yaitu:

1) Dana yang bersumber dari masyarakat, dan

2) Dana yang bersumber dari lembaga keuangan lain.

Sumber dana yang bersumber dari masyarakat terdiri dari tiga macam rekening, yaitu:

a) Tabungan (saving deposit) adalah simpanan dalam rupiah/valas milik pihak ketiga yang bukan bank yang penarikannya hanya dapat dilakukan menurut syarat tertentu yang disepakati seperti dengan slip penarikan. Dan penarikannya dapat dilakukan melalui syarat-syarat tertentu, serta dapat dilakukan setiap saat melalui kantor bank, automatic teller machine (ATM), dan kartu debet. Setiap penabung/nasabah akan diberikan buku tabungan sebagi bukti telah menyimpan dananya di bank tersebut. 
b) Simpanan berjangka (time deposit) atau dikenal dengan deposito merupakan simpanan dana masyarakat dimana penarikan dana tersebut hanya dapat dilakukan pada waktu tertentu sesuai dengan tanggal yang telah desepakati antara nasabah dengan pihak bank. Apabila nasabah menarik dananya tidak sesuai dengan waktu yang telah disepakati, nasabah akan dikenakan denda.

c) Giro adalah simpanan dalam rupiah/valas milik bank lain atau pihak ketiga yang ada pada bank yang penarikannya dapat dilakukan setiap saat dengan mengguanakan cek, bilyet giro, ATM maupun surat pereintah pembayaran lainnya.

d) Dana Transfer, transfer adalah jasa yang diberikan oleh bank berupa pemindahan dana antar rekening, uang tunai ke rekening, maupun rekening ke seseorang yang diterima secara tunai. Fasilitas transfer ini dapat dilakukan antarcabang pada bank itu sendiri maupun antar bank melalui fasilitas kliring.

e) Setoran Jaminan adalah sejumlah dana tertentu yang harus diserahkan ke nasabah yang mendapatkan jasa-jasa trertentu dari bank.

f) Modal adalah modal yang telah disetor, agio saham, cadangan yang dibentuk dari penyisihan laba bersih setelah atau sebelum pajak dan mendapat persetrujuan RUPS serta laba ditahan. ${ }^{32}$

Sumber dana yang bersumber dari lembaga keuangan diperoleh bank melalui:

a) Call Money adalah sumber dana yang diperoleh dari bank berupa pinjaman jangka pendek yang didapatkan dari interbank call money market.

b) Pinjaman Antarbank yaitu pinjaman dari bank lain berupa pinjaman jangka pendek dan menengah

32 M. Sulhan and Ely Siswanto, Manajemen Bank Konvensional Dan Syariah (Malang: UIN-Malang Press, 2008), 64-65. 
c) Bantuan Likuiditas Bank Indonesia (BLBI), sumber dana BLBI ini digunakan untuk memenuhi kebutuhan mendesak dalam jangka pendek.

d) Surat Berharga Pasar Uang (SBPU) adalah salah satu instrument Bank Indonesia yang digunakan untuk menghimpun dana atau menyalurkan dana

e) Fasilitas Diskonto Bank Indonesia, fasilitas ini digunakan bagi bank-bank yang mengalami kesulitan likuiditas atau sebagai upaya terakhir bank untuk mengatasi kondisi keuangannya. Fasilitas diskonto dari Bank Indonesia ini terdiri dua jenis, yaitu: a) fasilitas diskonto I, yang digunakan untuk memperlancar pengaturan dana sehari-hari, b) fasilitas diskonto II, yang digunakan untuk menanggulangi kesulitan likuiditas bank, sebagai akibat dari rencana penanaman dana yang tidak sesuai dengan penarikan. ${ }^{33}$

b. Sumber dana Bank Syariah

Bank Islam menjalankan fungsi-fungsi financing tersebut adalah dalam kapasitasnya sebagai mudharib dengan menggunakan dana yang diperoleh dari para nasabah sebagai Shahib al-Mal, yang menyimpan dan menanamkan dananya pada bank melalui rekeningrekening tersebut:

1) Rekening Koran (prinsip simpanan murni al-Wadiah) adalah Jasa simpanan dan dalam bentuk rekening Koran diberikan oleh bank Islam dengan prinsip alWadiah Yad Dhomanah, dimana penerima simpanan bertanggung jawab penuh atas segala kehilangan atau kerusakan yang terjadi pada aset titipan tersebut. Dengan prinsip ini, bank menerima simpanan dana dari nasabah yang memerlukan jasa penitipan dengan kebebasan mutlak untuk menariknya kembali sewaktu-waktu, sehingga bank memperoleh izin dari

33 Ade Arthesa and Edia Hendiman, Bank \& Lembaga Keuangan Bukan Bank (Jakarta: PT Indeks, 2009), 60-72. 
nasabah untuk menggunakan dana tersebut mengendap di bank. Nasabah sewaktu-waktu dapat menarik sebagian atau seluruh saldo yang mereka milki. Dengan demikian mereka memerlukan jaminan pembayaran kembali dari bank atas simpanan mereka. Semua keuntungan dari penggunaan dana tersebut selama mengendap di bank adalah menjadi hak bank. Bank diperbolehkan membrikan bonus pada nasabah atas kehendaknya sendiri, tanpa diikat oleh perjanjian. Bank menyediakan cek dan jasa-jasa lain yang berkaitan dengan rekening koran tersebut.

2) Rekening Tabungan adalah Bank menjamin pembayaran kembali simpanan mereka. Semua keuntungan atas pemanfaatan dana tersebut adalah milik bank, tetapi berbeda dengan rekening Koran, bank dapat memberikan imbalan keuntungan yang berasal dari sebagian keuntungan bank. Bank menyediakan buku tabungan dan jasa-jasa yang berkaitan dengan rekening tersebut.

3) Rekening investasi umum adalah Bank menerima simpanan dari nasabah yang mencari kesempatan investasi dari dana mereka dalam bentuk rekening investasi umum berdasarkan prinsip mudhorobah mutlaqoh. Simpanan di perjanjikan untuk jangka waktu tertentu. Bank dapat menerima simpanan tersenut untuk jangka waktu 1, 3, 6, 12, 24 bulan dan seterunya.

4) Rekening investasi khusus adalah Bank juga dapat menerima simpanan dari pemerintah atau nasabah korporasi dalam bentuk rekening simpanan khusus. Rekening ini juga dioperasikian berdasarkan prinsip mudharabah, tetapi bentuk investasi dan nisbah pembagian keuntungannya biasanya dinegosiasikan secara kasus per kasus. ${ }^{34}$

2. Penyaluran dan Penggunaan Dana Bank

\footnotetext{
${ }^{34}$ Rivai and Arifin, Islamic Banking: Sebuah Teori, Konsep, Dan Aplikasi, 303305 .
} 
a. Penyaluran dan Penggunaan Dana Bank Konvensional

Dana yang telah dihimpun oleh perbankan kemudian harus dialokasikan kembali menjadi aktiva produktif dengan tujuan menghasilkan keuntungan. Penggunaan dana tersebut sebagian digunakan aktifa produktif, yang berupa non-earning assets (aktiva yang tidak dapat menghasilkan keuntungan) dan earning assets (aktiva yang dapat menghasilkan keuntungan)

Berikut ini skema penggunaan dana:

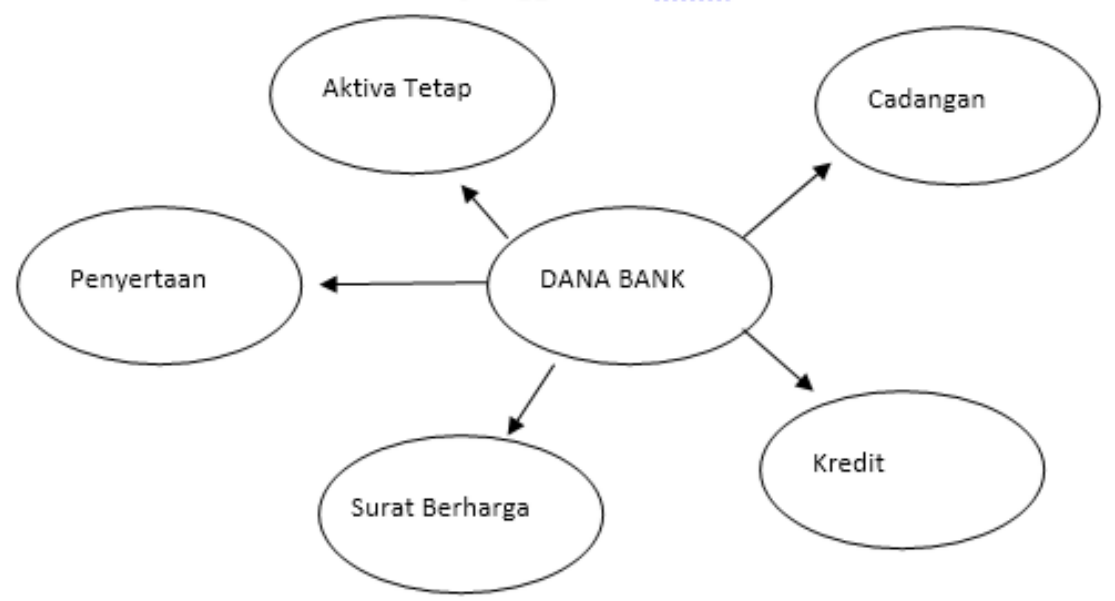

Penggunaan Dana untuk Aktiva Tetap adalah penggunaan dana untuk aktiva tetap berasal dari modal sendiri yang jumlahnya tidak boleh melebihi $50 \%$ dari total modal yang disetor. Penggunaan dana untuk aktiva tetap ini dikenal dengan penanaman dana yang tidak menghasilkan atau non-earning assets.

Penggunaan Dana untuk Cadangan adalah penggunaan dana untuk cadangan atau cadangan likuiditas bertujuan memenuhi likuiditas jengka pendek. Likuiditas adalah kemampuan bank untuk memenuhi kewajibannya ke nasabah yang dapat dilakukan setiap saat atau setiap waktu.

Penggunaan Dana untuk Kredit adalah penggunaan dana untuk kredit ini berdasarkan undang-undang nomor 10 tahun 1998 tentang perbankan adalah sebagai berikut: 
"Penggunaan dana untuk kredit adalah penyediaan uang atau tagihan yang dapat disamakan, berdasarkan persetujuan atau kesepakatan pinjam meminjam antara bank dengan pihak lain yang mewajibkan pihak peminjam untuk melunasi utangnya setelah jangka waktu tertentu dengan pemberian bunga." 35

Penggunaan Dana untuk Surat-surat Berharga, Perbankan nasional menggunakan dananya diantaranya untuk surat-surat berharga dengan tujuan meningkatkan permintaan. Diantara bentuk-bentuk surat berharga adalah secondary reserve (cadangan sekunder), Sertifikat Bank Indonesia (SBI), Surat Berharga Pasar Uang (SBPU).

Penggunaan Dana untuk Penyertaan, berdasarkan undang-undang nomor 10 tahun 1998 tentang perbankan, pada pasal 7 ayat c dijelaskan bahwa perbankan nasional dapat melakukan penyertaan ke perusahaan tertentu yang disebabkan adanya kegagalan kredit. ${ }^{36}$

b. Penyaluran dan Penggunaan Dana Bank Syariah

1) Produk pembiayaan dengan Prinsip Bagi hasil Ada dua macam kontrak dalam katagori ini yaitu:

a) Musyarakah (joint venture profit sharing)

Melalui kontrak ini, dua pihak atau lebih (termasuk bank dan lembaga keuangan bersama nasabahnya) dapat mengumpulkan modal mereka unutk membentuk sebuah perusahaan (syirkah al-inan) sebagai sebuah badan hukum (legal entity). Setiap pihak mempunyai bagian secara proporsional sesuai dengan konstribusi modal mereka dan mempunyai hak mengawasi (voting right) perusahaan sesuai dengan proporsinya. Untuk pembagian keuntungan, setiap pihak menerima bagian keuntungan secara proporsional dengan kontribusi modal masing-

${ }^{35}$ Undang-Undang Negara Republik Indonesia Nomor 10 Tahun 1998 Tentang Perbankan.

${ }^{36}$ Arthesa and Hendiman, Bank \& Lembaga Keuangan Bukan Bank, 73-77. 
masing atau sesuai dengan kesepakatan yang telah ditentukan sebelumnya. Bila perusahaan mengalami kerugian, maka kerugian itu juga dibebankan secara proporsional kepada masing-masing pemberi modal. Aplikasinya terhadap perbankan terlihat pada akad yang diterapkan pada usaha atau proyek dimana bank membiayai sebagian saja dari jumlah kebutuhan investasi atau modal kerjanya. Selebihnya dibiayai sendiri oleh nasabah. Akad ini juga diterapkan pada antar bank atau lembaga keuangan.

Dalam kontrak tersebut, salah satu pihak dapat mengambil alih modal pihak lain sedang pihak lain tersebut menerima kembali modal mereka secara bertahap. Inilah yang disebut dengan Musyarakah al-Mutanakishah. Aplikasinya dalam perbankan adalah pada pembiayaan proyek oleh bank bersama nasabahnya atau bank dengan lembaga keuangan lainnya, dimana bagian dari bank atau lembaga keuangan diambil alih oleh pihak lainnya dengan cara mengangsur. Akad ini juga dapat dilaksanakan pada mudharabah yang modal pokoknya dicicil, sedang usahanya berjalan terus dengan modal yang tetap.

b) Mudharabah (Trustee Profit Sharing)

Kontrak mudharabah adalah juga merupakan suatu bentuk Equity Financing, tetapi mempunyai bentuk yang berbeda dengan musyarakah. Di dalam mudharabah, hubungan kontrak bukan antar pemberi modal melainkan antara penyedia dana (Shahib al-Mal) dengan entrepreneur (Mudharib). Di dalam kontrak mudharabah, seorang mudharib, memperoleh modal dari unit ekonomi lainnya untuk tujuan melakukan perdagangan atau perniagaan. Mudharib dalam kontrak ini menjadi trustee atas modal tersebut. 
2) Debt Financing dengan prinsip jual beli dan sewa menyewa dan qard hasan.

Yang meliputi prinsip jual beli dilakukan pada transaksi-transaksi berikut:

a) Al Murabahah, yaitu kontrak jual beli dimana barang yang diperjual-belikan tersebut diserahkan segera, sedang harga atas barang tersebut dibayar kemudian hari secara sekaligus. Dalam prakteknya, bank bertidak sebagai penjual dan nasabah sebagai pembeli dengan kewajiban membayar secara tangguh dan sekaligus

b) Al Bai' Bitsaman Ajil, yaitu kontrak al-Murabahah dimana barang yang diperjual-belikan tersebut diserahkan dengan segera sedang harga atas barang tersebut dibayar di kemudian hari secara angsuran. Dalam prakteknya pada bank sama dengan murabahah, hanya saja kewajiban nasabah dilakukan secara angsuran.

c) Bai' as-Salam, yaitu kontrak jual beli dimana harga atas barang yang diperjual-belikan dibayar dengan segera, sedangkan penyerahan atas barang tersebut dilakukan kemudian. Bai' as-Salam ini biasanya dipergunakan untuk produk-produk pertanian yan berjangka pendek. Dalam hal ini, bank bertindak sebagai pembeli produk dan menyerahkan uangnya lebih dahulu sedangkan para nasabah menggunakannya sebagai modal untuk mengelola pertaniannya. Karena kewajiban nasabah kepada bank berupa produk pertanian, biasanya bank melakukan paralel salam yaitu mencari pembeli kedua sebelum saat panen tiba.

d) Bai' al-Istishna' hamper sama dengan bai' as-Salam yaitu kontrak jual beli dimana harga atas barang tersebut dibayar lebih dulu teapi dapat diangsur sesuai dengan jadwal dan syarat-syarat yang disepakati bersama, sedangkan barang yang dibeli diproduksi (Manufactured) dan diserahkan 
kemudian. Dalam prakteknya bank bertindak sebagai penjual (mustashni' ke 1) kepada pemilik atau pembeli proyek, dan mensubkannya kepada kontraktor (mustashni' ke 2).

Berkaitan dengan sewa dan sewa beli (Ijarah dan Ijarah wal Iqtina) oleh para ulama, secara bulat dianggap sebagai model pembiayaan yang dibenarkan oleh syariah Islam. Model ini secara konvensional dikenal sebagai lease dan financing lease. Al-Ijarah atau sewa, adalah kontrak yang melibatkan suatu batang (sebagai harga) dengan jasa atau manfaat aas barang lainnya. Penyewa juga dapat juga diberikan options untuk membeli barang yang disewakan tersebut pada saat sewa selesai, dan kontrak ini disebut al-Ijarah Wal Iqtina', dimana akad sewa terjadi antara $b \backslash$ ank (sebagai pemilik barang) dengan nasabah (sebagai penyewa) dengan cicilan sewanya sudah termasuk cicilan pokok harga barang.

Sedangkan qard hasan, dalam rangka mewujudkan tanggung jawab sosialnya, bank dapat memberikan fasilitas yang disebut al-Qard al-Hasan, yaitu penyediaan pinjaman dana kepada pihak-pihak yang patt mendapatkannya. Secara syariah peminjam hanya berkewajiban membayar kembali pokok pinjamannya, walaupun syariah membolehkan peminjam untuk memberikan imbalan sesuai dengan keikhlasannya tetapi bank sama sekali dilarang untuk menerima imbalan apapun. ${ }^{37}$

3. Jasa-Jasa Bank

a. Jasa Bank Konvensional

Jasa-jasa bank adalah salah satu aktivitas pada perbankan nasional yang bertujuan memberikan kemudahan bagi nasabah dalam melakukan transaksi keuangannya, dan disisi lain merupakan sumber penerimaan bagi

${ }^{37}$ Rivai and Arifin, Islamic Banking: Sebuah Teori, Konsep, Dan Aplikasi, 300303. 
perbankan. Sumber penerimaan yang berasal dari jasa bank dikenal dengan nama fee-based income. Antara lain jasa-jasa yang ditawarkan adalah:

1) Pembayaran Internasional, dalam melakukan perdagangan antar negara, pastinya membutuhkan jasa yang bisa mempermudah arus transaksi perdagangan, maka mereka yang melakukan transaksi antar negara bisa menggunakan jasa bank. Ada beberapa metode pembayaran sebagai pelayanan atau jasa bank ke nasabahnya, yaitu advance payment, open account, documentary collection, clean collection, dan letter of credit.

2) Letter of Credit (L/C), jika penjual diuntungkan maka secara ekstrem pembeli akan dirugikan, dan sebaliknya. Sehingga dibuatlah sistem pembayaran yang memberikan keuntungan ke kedua belah pihak, yakni pembeli dan penjual. Sistem tersebut dikenal dengan letter of credit (L/C). Sistem pembayaran ini merupakan jaminan tertulis dari bank penerbit atau perintah nasabah (pembeli/importir) untuk melakukan pembayaran ke beneficiary (penerima L/C atau penjual), asalkan beneficiary menyerahkan dokumen yang sesuai dengan persyaratan L/C tersebut.

3) Kliring adalah sarana perhitungan warkat antar bank yang dilaksanakan oleh Bank Indonesia dengan tujuan memperluas dan memperlancar lalu lintas pembayaran giral. Warkat-warkat yang diperhitungkan dalam kliring adalah cek, bilyet giro (BG), bukti penerimaan transfer, wesel bank untuk transfer, nota kredit/nota debet (lalu lintas giral/LLG) dan warkat lainnya yang disetujui oleh Bank Indonesia.

4) Bank Garansi adalah jaminan yang diterbitkan oleh bank berdasarkan keinginan pemohon yang ditujukan ke pihak ketiga, dengan tujuan memberikan jaminan berupa sejumlah uang tertentu ke pihak ketiga apabila ternyata pemohon melakukan wanprestasi (cedera

\section{maliyath}


janji). Fasilitas bank garansi ini umumnya dibutuhkan untuk proyek-proyek pemerintah maupun swasta.

5) Inkaso (collection) adalah penagihan warkat kliring (cek/BG warkat lainnya) ke bank penerbit di luar wilayah kliring, inkaso terdiri dua jenis yatu inkaso keluar dan inkaso masuk.

6) Cek Perjalanan (travelers cheque) adalah cek khusus yang diterbitkan oleh bank/lembaga keuangan dalam bentuk yang sudah tercetak dan dalam mata uang serta denominasi tertentu. Kegunaannya adalah memberikan kemudahan dan keamnanan bagi bagi orang yang melakukan perjalanan (khususnya ke luar negeri), karena yang bersangkutan tidak perlu membawa uang tunai.

7) Remittance adalah jasa pengiriman dan penerimaan uang dari luar negeri melalui fasilitas bank. Pada saat ini hamper semua perbankan nasional terutama bank devisa telah memiliki fasilitas remmitance, mengingat cukup besarnya penduduk Indonesia yang bekerja di luar negeri.

8) Kartu Kredit (credit card) adalah alat pembayaran berbentuk kartu dan berfungsi sebagai pengganti uang tunai, dan kartu ini digunakan sebagai alat pembayaran atas transaksi pembelian barang dan jasa.

9) Safe Deposit Box, jasa perbankan yang diberikan untuk memberikan rasa aman, atas penyimnpanan barang milik nasabah adalah fasilitas safe deposit box atau kotak pengamanan simpanan. Fasilitas ini terdapat dalam ruang khusus yang tahan api, dimana barangbarang nasabah disimpan dalam keadaan terkunci. Nasabah akan terjamin kerahasiaannya, serta terhindar dari resiko pencurian, kebakaran maupun kebanjiran.

10) Phone Banking, beberapa perbankan telah menyediakan fasilitas phone banking dan internet banking, yaitu fasilitas yang memudahkan nasabah 
melakukan semua transaksi keuangan hanya melalui telepon ataupun internet.

11) Cash Management merupakan strategi pengelolaan kas perusahaan dan dana nasabah. Terdapat beberapa definisi tentang jasa ini salah satunya, cash management adalah jasa yang diberikan bank ke nasabahnya untuk membantu pengeloalaan dana, sehingga nasabah dapat melakukan transaksi dengan lancar dan mendapatkan profit (keuntrungan) sesuai dengan yang diharapkan.

12) Pengiriman Uang (Transfer) adalah mekanisme pengiriman atau penerimaan sejumlah dana tertentu yang dilakukan bank atas perintah nasabah. ${ }^{38}$

b. Jasa Bank Syariah

Jasa-jasa yang ditawarkan di bank syariah adalah:

1) Rahn adalah akad menggadaikan barang dari satu pihak kepada pihak lain, dengan uang sebagai gantinya. Akad ini dapat digunakan sebagai tambahan pada pembiayaan yang beresiko dan memerlukan jaminan tambahan.

2) Wakalah adalah akad perwakilan antar dua pihak. Dalam aplikasinya dalam perbankan syariah, Wakalah biasanya diterapkan untuk penerbitan Letter of Credit (L/C) atau penerusan permintaan akan barang dalam negeridari bank di luar negeri (L/C ekspor). Wakalah juga diterapkan untuk mentransfer dana nasabah kepada pihak lain.

3) Kafalah adalah akad jaminan satu pihak kepada pihak lain. Dalam lembaga keuangan, akad ini terlihat dalam penerbitan garansi bank, baik dalam rangka mengikuti tender, pelaksanaa proyek, ataupun jaminan atas pemkbayaran lebih dulu.

4) Hawalah adalah akad pemindahan hutang/piutang suatu pihak kepada pihak lain. Prakteknya dapat

${ }^{38}$ Ibid., $88-112$ 
dilihat pada transaksi anjak piutang. Namun kebanyakan ulama tidak boleh mengambil manfaat (imbalan) atas pemindahan utang/piutang tersebut.

5) Ji'alah adalah suatu kontrak dimana pihak pertama menjanjikan imbalan tertentu kepada pihak kedua atas pelaksanaan suatu tugas/pelayanan yang dilakukan oleh pihak kedua untuk kepentingan pihak pertama. Prinsip ini dapat diterapkan oleh bank dalam menawarkan berbagai pelayanan dengan mengambil fee dari nasabah.

6) Sharf adalah transaksi pertukaran antara emas dengan perak atau pertukaran valuta asing, dimana mata uang asing dipertukarkan dengan mata uang domestik atau dengan mata uang asing lainnya. ${ }^{39}$

4. Keunggulan dan Kelemahan Bank Konvensional dan Bank Syariah

a. Keunggulan dan Kelemahan Bank Konvensional

Keunggulan yang dimiliki bank konvensional adalah:

1) Metode bunga telah lama dikenal masyarakat, Bank Konvensional lebih mudah menarik nasabah penyimpan dana sehingga lebihmudah mendapatkan modal

2) Bank Konvensional lebih kreatif dalam menciptakan produk-produk.

3) Nasabah terbiasa dengan metode bunga dibandingkan metode bagi hasil.

4) Persaingan antar bank lebih menggairahkan dapat memacu untuk bekerja lebih baik.

5) Peraturan perundang-undangan dan kebijakan Pemerintahan yanglebih mapan bagi bank konvensional, sehingga bank lebih leluasa untuk bergerak lebih pasti.

Kelemahan Bank Konvensial adalah:1) Faktor manajemen yang ditandai oleh inkonsistensi penyaluran kredit,

${ }^{39}$ Rivai and Arifin, Islamic Banking: Sebuah Teori, Konsep, Dan Aplikasi, 305306. 
campur tangan pemilik yang berlebihan dan manager profesional. 2) Kredit bermasalah karena prosedur pemberian kredit tidak potensi dan penampakan pemberian kredit pada grup sendiri dan kalangan tertentu. 3) Praktik curang seperti bank dalam bank dan transaksi fiktif. 4) Praktik spekulasi yang terlalu ambisius dan tanpa perhitungan, selain itu ada beberapa alasan mengapa banyak orang memanfaatkan.

b. Keunggulan dan Kelemahan Bank Syariah

Keunggulan Bank Syariah adalah:

1) Keunggulan Bank Islam terutama pada kuatnya ikatan emosional keagamaan antara pemegang saham, pengelola bank, dan nasabahnya. Dari ikatan emosional inilah dapat dikembangkan kebersamaan dalam menghadapi risiko usaha dan membagi keuntungan secara jujur dan adil.

2) Dengan adanya keterikatan secara religi, maka semua pihak yang terlibat dalam bank Islam adalah berusaha sebaik-baiknya dengan pengalaman ajaran agamanya sehingga berapa pun hasil yang diperoleh diyakini membawa berkah.

3) Adanya Fasilitas pembiayaan (al-mudharabah dan almusyarakah) yang tidak membebani nasabah sejak awal dengan kewajiban membayar biaya secara tetap.hai ini adalah memberikan kelonggaran phychologis yang diperlukan nasabah untuk dapat berusaha secara tenang dan sungguh-sungguh.

4) Dengan adanya sistem bagi hasil maka untuk penyimpan dana setelah tersedia peringatan dini tentang keadaan banknya yang bias diketahui sewaktuwaktu dari naik turunnya jumlah bagi hasil yang diterima.

5) Penerapan sistem bagi hasil dan ditanggalkannya sistem bunga menjadikan bank Islam lebih mandiri dari pengaruh gejolak moneter baik dari dalam maupun dari luar negeri.

Kelemahan Bank Syariah adalah:

\section{maliyath}


1) Utama Kelemahan Bank Islam adalah bahwa bank dengan sistem ini terlalu berprasangka baik kepada semua nasabahnya dan berasumsi bahwa semua orang yang terlibat dalam bank Islam adalah jujur. Dengan demikian bank Islam sangat rawan terhadap mereka yang beritikad tidak baik, sehingga diperlukan usaha tambahan untuk mengawasi nasabah yang menerima pembiayaan dari bank Islam.

2) Sistem bagi hasil memerlukan perhitunganperhitungan yang rumit terutama dalam menghitung bagian laba nasabah yang kecil-kecil dan yang nilai simpanannya di bank tidak tetap. Dengan demikian kemungkinan salah hitung setiap saat bias terjadi sehingga diperlukan kecermatan yang lebih besar dari bank konvensional.

3) Karena bank ini membawa misi bagi hasil yang adil, maka bank Islam lebih memerlukan tenaga-tenaga profesional yang handal dari pada bank konvensional. Kekeliruan dalam menilai proyek yang akan dibiayai bank dengan sistem bagi hasil akan membawa akibat yang lebih besar daripada yang dihadapi bank konvensional yang hasil pendapatannya sudah tetap dari bunga. ${ }^{40}$

\section{Penutup}

Berdasarkan pembahasan di atas dapat disimpulkan bahwa menurut Undang-undang Negara Republik Indonesia Nomor 10 Tahun 1998 tentang perbankan, bank adalah badan usaha yang menghimpun dana dari masyarakat dalam bentuk simpanan dan menyalurkannya kepada masyarakat dalam bentuk kredit dan atau bentuk-bentuk lainnya dalam rangka meningkatkan taraf hidup rakyat banyak. peranan perbankan konvensional dalam lembaga kegiatan ekonomi sama dengan perbankan Islam, sebagai lembaga dan penyaluran. Adapun

40 http://id.shvoong.com/social-sciences/economics/2109748-keunggulan-dankelemahan-bank-islam/ixzzlynCV46dt 3:41 PM 6/25/2012 
perbedaan yang paling menyolok adalah bank konvensional mempunyai pranata bunga, sedangkan bank Islam menggunakan sistem bagi hasil.

Berkaitan dengan sumber dana, terdapat dua sumber bagi kelangsungan usaha perbankan konvensional di Indonesia yaitu: dari dalam bank (internal) dan dari luar bank (eksternal). Sumber dana Bank Syariah adalah dalam kapasitasnya sebagai mudharib dengan menggunakan dana yang diperoleh dari para nasabah sebagai Shahib al-Mal, yang menyimpan dan menanamkan dananya pada bank melalui rekening-rekening.

Berkaitan dengan Penyaluran dan Penggunaan Dana, pada Bank Konvensional Dana yang telah dihimpun oleh perbankan kemudian harus dialokasikan kembali menjadi aktiva produktif dengan tujuan menghasilkan keuntungan. Penyaluran dan Penggunaan Dana di Bank Syariah adalah melalui Produk pembiayaan dengan Prinsip Bagi hasil dan Debt Financing dengan prinsip jual beli dan sewa menyewa dan qard hasan.

Diantara keunggulan bank konvensional adalah metode bunga telah lama dikenal masyarakat dan bank konvensional lebih kreatif dalam menciptakan produk-produk, sedangkan pada bank syariah sistem bagi hasil memerlukan perhitunganperhitungan yang lebih rumit dibanding bank konvensional. Meski demikian bank syariah memiliki keunggulan yaitu sistem bagi hasil tersebut lebih adil dibanding sistem bunga.

\section{Daftar Pustaka}

A. Perwataatmadja, Karnaen, and Syafi'i Antonio. Apa Dan

Bagaimana Bank Syariah. Yogyakarta: Dana Bhakti Wakaf, 1992.

Albuquerque, Martim de. Notes and Queries. London: George Bell, 1855.

Arifin, Zainul. Memahami Bank Syariah: Lingkup, Peluang,

Tantangan, Dan Prospek. Jakarta: Alfabet, 1999.

Arthesa, Ade, and Edia Hendiman. Bank \& Lembaga Keuangan

Bukan Bank. Jakarta: PT Indeks, 2009.

Goldfeld, Stephen M., and Lester V. Chanler. Ekonomi, Uang Dan

Bank, Terj. A. Hasjmi Ali. Jakarta: Bina Aksara, 1988. 
Harahap, Sofyan Syafii. Akuntansi Islam. Jakarta: Bumi Aksara, 1997.

Hoggson, N. F. Banking Through the Ages. New York: Dodd, Mead \& Company, 1926.

Kasmir. Manajemen Perbankan. Jakarta: Rajawali Press, 2000. Muhammad. Audit \& Pengawasan Syariah Pada Bank Syariah, n.d.

Raharjo, Dawam. Bank Indonesia Dalam Kilasan Sejarah Bangsa. Jakarta: LP3ES, 1995.

Reed, Edward B., and Edward K. Gill. Bank Umum Terj. St. Dianjung. Jakarta: Binai Aksara, 1995.

Reed, Edward W, and Edward K Gill. Bank Umum, Penerjemah St. Dianjung. Jakarta: Bina Aksara, 1995.

Rivai, Veithzal, and Arviyan Arifin. Islamic Banking: Sebuah Teori, Konsep, Dan Aplikasi. Jakarta: Bumi Aksara, n.d. Saeed, Abdullah. Islamic Banking and Interest. Leiden: EJ. Brill, 1996.

Shadily, Hasan. Ensiklopedia Indonesia. Jakarta: Ikhtiar Baru van Hoeve, 1966.

Sinungan, Muchdarsyah. Uang Dan Bank. Jakarta: Rineka Cipta, 1991.

Sulhan, M., and Ely Siswanto. Manajemen Bank Konvensional Dan Syariah. Malang: UIN-Malang Press, 2008.

Sumitro, W. Asas-Asas Perbankan Islam Dan Lembaga-Lembaga Terkait (BMUI \& Takaful) Di Indonesia. Jakarta: Raja Grafindo Persada, 1996.

Suyatno, Thomas. Kelembagaan Perbankan. Jakarta: Gramedia, 1987.

Tohirin, Ahmad. "Sewindu Bank Syariah Indonesia." Harian Kedaulatan Rakyat. Yogyakarta, April 2000.

Undang-Undang Negara Republik Indonesia Nomor 10 Tahun 1998 Tentang Perbankan, n.d. 